SEJ (School Education Journal)

Vol. 11 No. 3 Desember 2021

\title{
MEMBENTUK KARAKTER PESERTA DIDIK MELALUI PEMBELAJARAN IPS DI MI TARBIYATUS SHIBYAN
}

\author{
Zahratun Naemah, Rifatul Fadhila, Veni Veronica Siregar \\ Surel:muqowim@uin-suka.ac.id
}

\begin{abstract}
This investigation expects to break down how to shape the personality of understudies through friendly examinations learning at MI Tarbiyatus Shibyan The exploration technique utilized is subjective with an enlightening methodology that is library research. In light of the information acquired, the analysts tracked down that in molding the personality of understudies through friendly investigations learning, in particular by utilizing the CTL learning strategy. This examination likewise contributes in giving a nitty gritty depiction of the use of the joining of character esteems with science to be utilized as a source of perspective for the execution of instructing and learning exercises. Furthermore, the examination is additionally done to help educators and scholastic activists so that there is no detachment between strict information and general science.
\end{abstract}

Keywords : Character, IPS, Madrasah Ibtidaiyah

\begin{abstract}
ABSTRAK
Penelitian ini bertujuan untuk mengetahui bagaimana membentuk kepribadian siswa melalui pembelajaran investigasi ramah di MI Tarbiyatus Shibyan. Strategi pemeriksaan yang digunakan bersifat subjektif dengan metodologi grafis. Informasi yang diperoleh dari pemeriksaan ini merupakan konsekuensi dari pertemuan dan persepsi. Berdasarkan informasi yang diperoleh, para ahli melacak bahwa dalam membentuk kepribadian siswa melalui penelitian yang ramah memahami, menggunakan strategi pembelajaran CTL. Pemeriksaan ini juga berkontribusi dalam memberikan gambaran poin demi poin tentang pemanfaatan koordinasi nilai-nilai karakter dengan sains untuk digunakan sebagai semacam perspektif dalam pelaksanaan latihanlatihan pembelajaran. Terlebih lagi, pemeriksaan tersebut juga dilakukan untuk membantu para pengajar dan aktivis keilmuan agar tidak ada pemisahan antara ilmu-ilmu ketat dan umum.
\end{abstract}

Kata Kunci : Karakter, IPS, Madrasah Ibtidaiyah

\section{PENDAHULUAN}

"Sesungguhnya aku telah menciptakan hamba- hambaku dalam keadaan lurus, suci dan bersih. Kemudian datanglah setan- setan yang menggelincirkan mereka dan menyesatkan dari kebenaran agama mereka. Dan setan-setanpun telah mengharamkan segala sesuatu bagi mereka apa- apa yang telah aku halalkan". Penggalan hadist diatas 
menggambarkan bahwasanya kefitrahan yang telah dianugerahkan Allah kepada manusia menuntun mereka untuk selalu berbuat kebaikan. Terdapat anggapan bahwa fitrah manusia yang cenderung berbuat baik itu berasal dari rasionalitas manusia itu sendiri yaitu wilayah pengetahuan atau daya nalarnya bukan dari hati atau rohani manusia.

Namun, pengaruh lingkungan dan social juga sangat berpengaruh dalam menumbuhkan kefitrahan manusia. Ibnu Jazzar Al Qairawani seorang filsuf menjeleskan bahwa "sebenarnya sifat buruk yang ada pada diri manusia bukanlah lahir dari fitrah mereka, namun dikarenakan kurangnya peringatan sejak dini dari orang tua dan pendidik". Sifat- sifat buruk yang timbul dari sejak dini jika diabaikan maka semakin dewasa semakin sulit meninggalkan sifat- sifat buruknya. Dan jika itu terjadi maka akan semakin mengakar kuat dalam kebiasaan hidupnya. Kepribadian dan watak yang buruk ini yang harus dihindari dengan membentuk karakter yang berakhlaqul karimah.

Dalam lingkup pendidikan, pendidikan karakter akan membawa dan mengarahkan siswa mengenal konsep baik dan buruk sesuai dengan tahap perkembangan dan usia mereka. Pendidikan karakter akan mengarahkan siswa menjadi generasi muda yang memiliki etika baik, bertanggung jawab dan peduli salah satunya yaitu melalui pembiasaan dengan menekankan nilai- nilai kebaikan pada tiap mata pelajaran tidak hanya pada mata pelajaran agama namun juga pada mata pelajaran umum. Karena sejatinya kedua ilmu tersebut (agama dan umum) sama- sama ingin membumikan hal- hal yang positif pada siswa. Tidak ada pemisah diantara kedua ilmu tersebut, semuanya ssaling berhubungan, saling berkaitan dan saling membutuhkan satu sama lain.

Melalui penyesuaian tersebut, diyakini bahwa pengajaran karakter dapat dilakukan di setiap mata pelajaran, baik dalam mata pelajaran ketat maupun mata pelajaran yang sangat luas. Siswa Madrasah Ibtidaiyah berada pada tahap "anak berakal" atau nyonya besar. Saat ini siswa perlu diakui oleh temantemannya sehingga perilaku mereka secara umum akan disesuaikan dengan apa yang umumnya diharapkan oleh teman-temannya tanpa mengurangi apakah kegiatan tersebut bermanfaat bagi mereka atau sebaliknya. Dalam menyikapi peristiwa tersebut, wali dan guru dapat membantu peningkatan siswa, salah satunya dengan menjaga hubungan baik dengan mereka melalui surat menyurat, dan mengambil bagian dalam berpikir kritis.

Ilmu Pengetahuan Sosial (IPS) merupakan salah satu mata pelajaran yang dapat mengembangkan dan menanamkan pendidikan berkarakter, mengingat mata pelajaran ini dapat memfasilitasi dan memberikan kesemptan yang seluas- luasnya kepada siswa untuk menunjukkan saling 
memahami dan menghargai eksistensi masing- masing, menunjukkan kepekaan terhadap perbedaan diantara siswa yang dapat dikembangkan menjadi perasaan empati dalam diri siswa. Melalui mata pelajaran IPS yang berkarakter dapat membekali siswa untuk menjadi pribadi yang memiliki rasa social yang tinggi terhadap lingkungannya. Dengan haldemikianlah yang perlu ditanmakan dan dikuatkan dalam diri siswa sejak dini dengan tekhnik pengintegrasian yang tepat, tentunya didukung dengan keteladan dari orang tua yang merupakan madrasah pertama bagi siswa.

Dikotomi ilmu pengetahuan seringkali ditemui disekitar kita. Hal ini terjadi karena konsep berfikir manusia yang seringkali memandang sebelah mata lmu pengetahuan.padahalah jika kita telusuri lebih dalam, sesungguhnya semua ilmu itu datangnya dari Allah SWT (baik itu ilmu agama ataupun ilmu umum). Sebagian ilmu tersebut diwahyukan kepada manusia- manusia pilihan-Nya dan sebagiannya lagi diperoleh manusia melalui indera, akal dan juga hatinya. Kedua ilmu ini (Agama dan umum) bagaikan dua sisi mata uang logam yang tidak bisa dipisahkan dan saling membutuhkan karena nilai dan karakter kedua ilmu tersebut sama- samaingin membumikan hal- hal yang positif bagi manusia.

Dengan demikian perlu diadakan langkah pengintegrasian terhadap keduanya agar tidak terjadi lagi dikotomi ilmu pengetahuan. Berangat dari permasalahan tersebut kiranya penulis perlu menelusuri lebih dalam apakah sejuah ini pengintegrasian telah diterapkan di lembaga- lembaga utamanya pada tingkat Madrasah Ibtidaiyah (MI) melalui kegiatan wawancara yang akan penulis lakukan kepada salah satu guru IPS kelas II di MI Tarbiyatus Shibyan Lembung Timur Lenteng Sumenep.

\section{METODE PENELITIAN}

Penelitian yang dilakukan menggunakan jenis penelitian kualitatif dengan pendekatan deskriptif analisis. Penelitian kualitatif adalah jenis penelitian yang digunakan untuk meneliti objek secara alami, dalam hal ini peneliti sebagai instrumen kunci (Sugiyono, 2016). Sumber penelitian ada dua, yaitu sumber primer yang berasal dari bukubuku maupun jurnal-jurnal online yang terakreditasi dan dipercaya kredibilitasannya sehingga mampu untuk menunjang hasil penelitian, serta sumber sekunder sebagai bahan pendukung yaitu hasil wawancara terhadap guru kelas II MI Tarbiyatus Shibyan.

\section{HASIL PENELITIAN DAN PEMBAHASAN}

Dalam Kegiatan pembelajaran siswa merupakan komponen utama karena dalam proses pembelajaran guru selalu dihadapkan dengan keunikan dari masing-masing siswa yang 
mengisyaratkan adanya perbedaan masing- masing individu baik dari sisi kemampuannya, motivasinya dalam belajar dan juga kecepatan belajar. Dengan perbedaan- perbedaan yang terdapat pada masing- masing siswa sudah menjadi kewajiban guru dalam mengupayakan bagaimana caranya supaya dalam kegiatan pembelajaran siswa berperan aktif dalam menjalani pembelajaran. Selain itu kemajuan ilmu pengetahuan dan teknologi akan membawa dampak baik yang bersifat positif maupun negatif

Menurut Soedijarto sebagaimana dikutip oleh M. Hosna dalam bukunya bahwa seorang guru mempunyai kedudukan dan peran yang penting dalam mencapai kualitas pendidikan. Guru sebagai pengelolah kegiatan pembelajaranlah yang dapat menentukan kualitas proses belajar yang pada akhirnya kulaitas dari proses belajar tersebut berkaitan dengan kualitas belajar siswa. Kualitas belajar siswa ditentukan melalui penyatuan antara kemampuan dalam diri siswa dengan kegigihan siswa dalam belajar. Kegigihan siswa dalam belajar dapat diperoleh dari motivasi yang dimiliki siswa tersebut, dengan demikian memberikan perhatian dan menumbuhkan motivasi belajar siswa sangatlah penting.

Pendidikan karakter dulunya hanya diterapkan padadua mata pelajaran saja yaitu PKN dan agama. Namun realitasnya penanaman serta pembentukan karakter melalui dua mata pelajarantersebut tidaklah cukup. Dalam membentuk karakter siswadapat melibatkan lebih dari kedua mata pelajaran tersebuT salah satunya yaitu IPS. Budimansyah (2010) menjelaskan bahwa urgennya menanamkan dan membentuk karakter siswa tertuang dalam Undang-undang Nomor 20 Tahun 2003 tentang Sistem Pendidikan Nasional Pasal 3. Pasal 3 UU tersebut menjelaskan bahwa "Pendidikan nasional berfungsi untuk mengembangkan kompetensi dan mencetak karakter untuk mencerdaskan kehidupan bangsa dan untuk mengembangkan kemampuan siswa dengan harapan menjadi insan yang bertaqwa.

Pernyataan UU tersebut dapat kita simpulkan bahwa fungsi pendidikan dalam membentuk karakter siswa bukan hal baru dan hingga saat inipendidikan karakter mulai dikembangkan dalam berbagai mata pelajaran salah satunya IPS. Pengintegrasian pendidikn karakter dalamkegiatan pembelajaran dilaksanakan melalui tahapan perencanaan sampai evaluasi pembelajaran. Pada tahap perencanaan dalam mengintegrasikan pendidikan karakter hal pertama yang perl dilakukan yaiu dengan menganalisis kompetensi dasar, mengembangkan silabus, membuat RPP serta menyiapkan bahan ajar yang akan digunakan. Urgen untuk kita ketahui bahwa dalam dalam mengidentifikasi nilai- nilai karakter tidak bertujuan untuk memberikan batasan terhadap nilai yang terdapat di kompetensi dasar. Dalam 
mengembangkan silabus perlu ditambah nilai- nilai karakter yang akan diintegrasikan dalam kegiatan pembelajaran. Alangkah baiknya Nilai tersebut merupakan nilai yang dengan mudah dikembangkan dalam kegiatan pembelajaran. Kemudian kegiatankegiatan yang hendak dilakukan memerlukan penyesuaian dengan karakter yang akan dikembangkan.

Pada tahap pelaksanaan pembelajaran dimulai dari kegiatan pendahuluan, inti, dan penutup. Hal tersebut harus dilaksanakan agar siswa dapat mengimplementasikan dan mempraktekkan nilai karakter yang telah guru targetkan. Salah satu metode yang dapat membantu terealisasikannya nilai karakter pada siswa yaitu CTL. Pengunaan CTL dapat diaplikasikan terhadap semua tahapan pembelajaran. Komalasari (2009) menjelaskan bahwa CTL sangat efektif diterapkan untuk membentuk karakter peserta didik karena beliau berasumsi bahwa kegiatan pembelajaran akan terjadi jika siswa dapat menemukan hal hal bermakna antara berfikir abtrak dengan kehidupan nyata. Pada esensinya pembelajaran CTL dapat membantu guru dalammengaitkan materi pelajaran dengan kehidupan nyata siswa. Sehingga dengan CTL siswa tidak hanya memperoleh teori teori saja, namun mereka langsung mengaitkannya dengan kehidupan sehari-hari.

MI Tarbiyatus Shibyan merupakan salah satu lembaga swasta yang terletak di Desa Lembung Timur Lenteng Sumenep. Lembaga ini merupakan lembaga swasta yang memiliki murid terbanyak se- kecamatan Lenteng. Lembaga ini terkenal dengan kedisiplinanya yang sangat tinggi baik dari siswanya ataupun gurunya, sehingga tidak heran jika banyak orang tua yang mempercayai untuk menyekolahkan putra putrinya dilembaga MI Tarbiyatus Shibyan. Kedisiplinan yang ditanamkan kepada siswa dan guru di MI Tarbiyatus Shibyan akan menjadi jalan menuju pendidikan yang berkualitas dan berkarakter, hal ini diperkuat dengan visinya yaitu "Mencetak insan yang beriman, bertaqwa, berilmu, dan beramal serta memiliki akhlaqul karimah".

Pendidikan dapat dikatakan berkualitas apabila orang-orang didalamnya memiliki jiwa dan kepribadian yang berkualitas pula terutama seorang guru sebagai tonggak utama dalam mendidik siswanya, guru tidak hanya mampu untuk mentransfer ilmu kepada siswa namun guru juga harus memiliki kemauan dan keikhlasan memberikan ilmunya kepada siswa karena bagi siswa guru adalah rumah pengetahuan, sebuah ruang akademik yang bersifat bebas. Berdasarkan informasi yang diperoleh dari guru kelas II MI Tarbiyatus Shibyan, untuk meningkatkan kualitas guru dan siswa yaitu:"pertama untuk meningkatkan kualitas guru pertama kami harus membangun kepercayaan, memberikan 


\section{SCHOOL EDUCATION JOURNAL VOLUME 11 NO. 3 DESEMBER 2021}

penyadaran agar bagaimana seorang guru memiliki jiwa pengertian, kedua kompetensi guru perlu diasah dengan mengikuti berbagai kegiatan seperti seminar dan sebagainnya, namun yang paling utama kami harus memiliki aqidah, kepercayaan yang kuat membangun anak islam dan anak negeri ini sehingga mereka bisa lebih baik, mengenai siswa pendidikan mereka, kemampuan mereka kami control, terus akhlak mereka kami tuntun kami arahkan serta hal-hal lain yang berkaitan dengan kemajuan pendidikankami terus support, kami terus pantau, kami terus berikan solusi bagaimana anak bisa meningkatkan pendidikannya sehingga kompetensinya menjadi lebih baik, akhlaknya lebih beradap dan mereka siap menghadapi perkembangan zaman dan pergeseran moral seperti sekarang ini".

Kegiatan observasi yang penulis lakukan pada Kegiatan Belajar Mengajar di MI Tarbiyatus Shibyan sebanyak 1 kali di kelas II pada mata pelajaran IPS. Kegiatan observasi dan wawancara ini penulis lakukan untuk mendapatkan informasi mengenai pengintegrasian ilmu pengetahuan di lembaga MI. Dari hasil pengamatan dan wawancara tersebut, secara umum dalam proses pembelajaran guru telah melakukan pengintegrasian (perpaduan) antara ilmu agama dan ilmu umum. Hal ini juga diperkuat dari hasil wawancara dengan guru kelas II (Siti Sulaiha) menjelaskan bahwa:
"Awal pembelajaran seperti biasa yang dilakukan didahuli pengucapan salam, terus mengisi absen terus ada lagi kebiasaan-kebiasaan lain seperti hafalanhafalan surat-surat pendek, lagu-lagu atau kebiasaan lain tergantung pelajaran yang akan kita pelajari. Jadi begini mbak, karena saat ini dilembaga ini menggunakan kurikulum 2013 yang mana pada kurikulum ini semua aspek pengetahuan, sikap dan keterampilan anak itu diprioritaskan. Jadi dalam kegiatan pembelajaran kami tidak hanya dituntut untuk membuat siswa tau tentang apa pengertian kebersihan. Jadi tidak hanya teori saja, mislanya materi saat ini di kelas II belajar tentang pelestarian lingkungan alam dan buatan, Jadi kami tidak hanya menjelaskan teorinya saja kepada siswa tapi bagaimana caranya ketika siswa belajar tentang pelestarian lingkuangan ini mereka dapat mengambil nilai- nilai tentang pelestarian lingkungan alam. Misalnya tadi itu sebelum istirahat anakanak saya suruh untuk memperhatikan lingkungan kelasnya apakah kotor atau tidak, jika ada sampah disekitar bangkuna daya perintahkan mereka untuk mengambilnya dan membuangnya di tempat sampah. Jadi hari ini meeka belajar teorinya dan sekaligus mereka dapat menerapkan apa yang mereka pelajari saat ini juga".

Dari hasil penjelasan ibu Sit (guru kelas II) di MI Tarbiyatus Shibyan, bahwasanya dalam pembelajaran IPS (Pelestarian Lingkungan Alam dan Buatan), guru tidak hanya 
menyampaikan materi tentang apa itu pengertian lingkungan, bagaiamana cara melestarikan lingkungan, lebih dari itu guru dapat mengambil nilainilai yang terdapat pada materi tersebut sehingga dapat menjadikan pembelajaran yang bermakna bagi siswa yang berdampak terhadap sikap siswa. Sehingga ketika pebelajaran telah selesai siswa memiliki pengalaman yang bermakna terhadap apa yang mereka peroleh pada saat kegiatan pembelajaran berlangsung. Seperti yang penulis juga amati saat kegiatan pembelajaran berlangsung, saat guru menjelaskan bagaimana cara melestarikan lingkungan buatan maka guru memberikan contoh dengan menyuruh siswa untuk membersihkan sampah- sampah yang ada disekitar siswa. Kegiatan demikian secara tidak langsung berkaitan dengan ajaran pada.

\section{Pembahasan}

Dalam mengimplementasikan pengintegrasian nilai- nilai keagamaan pada mata pelajaran IPS ini tentu akan ada hambatan dan kesulitan yang akan dialami oleh seorang guru. Berdasarakan hasil wawancara yang penulis lakukan, Ibu Sit memaparkan bahwa:

"Hambatan yang sering kali kami alami saat mengintegrasikan nilainilai keagamaanpada mata pelajaran umum seperti mata pelajaran yang saya pegang yaitu IPS adalah bagaimana menyadarkan saya pribadi sebagai seorang guru, karena sering kali kita memberikan pemahamanpemahaman kepada siswa sedangkan kami sendiri belum tentu menjalaninya. Padahal seorang guru merupakan suri teladan atau contoh yang baik bagi peserta didik. Akibatnya apa? Ya kadang ketika saya suruh mereka untuk membersihkan kelas sebagai cara untuk melestarikan lingkungan buatan sesuai materi pada hari ini,kadang ada salah satu dari mereka yang tidak menghiraukan dengan apa yang saya perintahkan. Maka langkah yang saya ambil saat melihat hal yang demikian, saya juga ikut membersihkan kelas ini sebagai bukti cinta saya terhadap lingkungan. Saat saya ikut membersihkan kelas ini, si Anak akhirnya juga ikut membersihkan kelas".

\section{SIMPULAN}

Pembentukan karakter pada siswa usia Madrasah Ibtidaiyah dapat ditanamkan dalam pembelajaran IPS, salah satunya yaitu dengan menerapkan pendekatan CTL. Integrasi pendidikan karakter dalam kegiatan pembelajaran dilaksanakan mulai dari tahap perencanaan, pelaksanaan dan evaluasi pembelajaran.pembentukan karakter melalui bebagai mata pelajaran salah satunya IPS diharapkan tidak ada lagi dikotomi antara ilmu agama dengan ilmu umum dan paradigma bahwa pendidikan karakter hanya dapat dilakukan melalui mata pelajaran agama. 
DAFTAR RUJUKAN

Aty Mulyani, dkk. 2018. Integrasi Ilmu Pengetahuan Alam dan Nilai-nilai Islam untuk Pembangunan Karakter Peserta Didik di Madrasah Aliyah. JEMST; Journal Of Education in Mathematics, Science, and Technology, 1(1), 16-19.

Budimansyah, Dasim., Yadi R., Nandang R. 2010. Model Pendidikan Karakter di Perguruan Tinggi. Bandung: UPI. Calista, W. 2019. Integrasi Mata Pelajaran IPA Dengan Nilai-Nilai Islam Melalui Pendekatan Bayanidi Kelas IIIC MI Negeri 1. Yogyakarta. JIP: Jurnal Ilmiah PGMI, 5(2), 223-236.

Depdiknas. 2003. UU RI Nomor 20

Tahun 2003 Tentang Sistem Pendidikan Nasional. Jakarta: Dirjen Pendidikan Dasar dan Menengah.

Fajrin, Laila dan Muqowim. 2020.

Problematika Nilai- Nilai

Keislaman pada Pembelajaran IPA di MI Miftahul Huda Jepara. ELEMENTARY: Islamic Teacher Journal 8, no. 2, 295-312.

Hamdani Hamid. 2013. Pendidikan Karater Perspektif Islam. Bandung: Pustaka Setia

Hosnan, M. 2014. Pendekatan Saintifik dan Kontekstual Pembelajaran Abad 21. Bogor: Ghalia Indonesia. Komalasari, K. 2009. The Effect of Contextual Learning in Civic Education on Students' Civic
Competence. Journal of Social Sciences. 5(4): 261-270.

Kesuma, \& Dharma, dkk. 2011. Pendidikan Karakter Kajian Teori dan Praktek di Sekolah. Bandung: Remaja Rosdakarya.

Marzuki. 2015. Pengintegrasian Pendidikan Karakter dalam Pembelajaran di Sekolah. Yogyakarta: Universitas Negeri Yogyakarta.

Muchlas Samani dan Hariyanto. 2013. Konsep dan Model Pendidikan Karakter, cet. 3. Bandung: Remaja Rosdakarya.

Muchlas Samani, \& Hariyanto, M.S. 2011. Konsep Dan Model Pendidikan Karakter. Bandung: Remaja Rosdakarya.

Munandar, U. 2012. Pengembangan kreativitas anak berbakat. Departemen Pendidikan \& Kebudayaan. Bandung: Reneka Cipta.

Thoboni, Muhammad \& Arif Mustofa. 2015. Belajar dan Pembelajaran. Yogyakarta: Ar- Ruzz Media. 

